\title{
In vitro phytotoxicity of Mikania laevigata Schultz Bip. ex Baker extracts on Lactuca sativa $L$. and Bidens pilosa L.
}

\author{
Lívia Maria de Lima Santos * \\ Adenilson Henrique Gonçalves \\ Universidade Federal de Lavras, Departamento de Agricultura, Laboratório de Fitoquímica \\ Caixa Postal 3037, CEP 37.200-000, Lavras - MG, Brazil \\ * Autor para correspondência \\ livia-linne@hotmail.com
}

Submetido em 20/10/2019

Aceito para publicação em 28/04/2020

\section{Resumo}

Fitotoxicidade in vitro de extratos de Mikania laevigata Schultz Bip. ex de Baker sobre Lactuca sativa L. e Bidens pilosa L. Extratos vegetais possuem metabólitos secundários que podem atuar como bioherbicidas com a vantagem de promoverem menores riscos ao ambiente. Mikania laevigata pertence à família Asteraceae e possui a cumarina 1,2-benzopirona como marcador químico, capaz de inibir ou estimular a germinação e crescimento de plantas adjacentes. Diante do exposto, objetivou-se avaliar a fitotoxicidade dos extratos aquoso e etanólico de M. laevigata sobre Lactuca sativa (alface) e Bidens pilosa (picão preto). Foram testadas cinco concentrações $\left(0,1 ; 1,0 ; 1,5 ; 2,0\right.$ e 3,0 mg.mL $\left.\mathrm{mL}^{-1}\right)$ dos extratos, aquoso e etanólico, em experimentos separados, e água destilada como controle. Para isso, foram avaliados a porcentagem de germinação, o índice de velocidade de germinação, o crescimento inicial e os teores de peróxido de hidrogênio $\left(\mathrm{H}_{2} \mathrm{O}_{2}\right)$ e do malonaldeido (MDA). $\mathrm{Na}$ presença do extrato etanólico, as espécies (alface e picão preto) reduziram 85 e $90 \%$ da germinação, respectivamente. O comprimento da radícula, na menor concentração dos extratos, não foi afetado. Entretanto, na concentração de $2,0 \mathrm{mg} \cdot \mathrm{mL}^{-1}$, as reduções foram de $85 \%$, para alface, e $65 \%$, para picão preto. O aumento do teor de $\mathrm{H}_{2} \mathrm{O}_{2}$ foi dose dependente, ou seja, conforme o aumento da concentração dos extratos maior a produção de peróxido, seguido do aumento do MDA para alface e picão preto. As plântulas cultivadas na concentração de $3 \mathrm{mg} \cdot \mathrm{mL}^{-1}$ do extrato etanólico sofreram necrose, impossibilitando as análises subsequentes. Os extratos da M. laeviagata nas concentrações 2,0 e 3,0 mg. $\mathrm{mL}^{-1}$ demonstraram fitointoxicação com aumento do estresse oxidativo nas espécies alface e picão preto.

Palavras-chave: Controle biológico; Cumarina; Fitointoxicação; Guaco

\section{Abstract}

Plant extracts have secondary metabolites that can act as bioherbicides, with the advantage of being more environmentally friendly. Mikania laevigata belongs to the family Asteraceae and has coumarin 1,2-benzopyrone as a chemical marker, which is capable of inhibiting or stimulating the germination and growth of adjacent plants. Thus, the objective of this work was to evaluate the phytotoxicity of aqueous and ethanolic extracts of M. laevigata on Lactuca sativa (lettuce) and Bidens pilosa (beggarticks). Five 
concentrations $\left(0.1,1.0,1.5,2.0\right.$ and $\left.3.0 \mathrm{mg} \cdot \mathrm{mL}^{-1}\right)$ of aqueous and ethanolic extracts were tested in separate experiments, with distilled water as the control. Germination percentage, germination speed index, initial growth and the content of hydrogen peroxide $\left(\mathrm{H}_{2} \mathrm{O}_{2}\right)$ and malonaldehyde (MDA) were evaluated. In the presence of the ethanolic extract, germination of the species (lettuce and beggarticks) was reduced by $85 \%$ and $90 \%$, respectively. Radicle length, for the lowest concentration of the extracts, was not affected. However, at a concentration of $2.0 \mathrm{mg} \cdot \mathrm{mL}^{-1}$ the reductions were $85 \%$ for lettuce and $65 \%$ for beggarticks. The increase of $\mathrm{H}_{2} \mathrm{O}_{2}$ content depended on the dose, where the greater the concentration of the extracts, the greater the production of peroxide, followed by an increase in MDA for lettuce and beggarticks. Seedlings grown in a concentration of $3.0 \mathrm{mg} \cdot \mathrm{mL}^{-1}$ of the ethanolic extract were subjected to necrosis, making subsequent analyses impossible. The M. laeviagata extracts at concentrations of 2.0 and $3.0 \mathrm{mg} \cdot \mathrm{mL}^{-1}$ demonstrated phytotoxicity, with increased oxidative stress in lettuce and beggarticks.

Key words: Guaco; Coumarin; Phytotoxicity; Biological control

\section{Introduction}

Weeds negatively impact agricultural production because they compete with crops for environmental resources and can harbor pests and diseases, reducing productivity and increasing production costs, especially those related to synthetic herbicides (MUSHTAQ et al., 2020). Despite the effectiveness of these products at controlling invasive plants in cultivated areas, inappropriate use contaminates the environment, mainly water and soil (ISMAIL et al., 2016).

Therefore, alternative and less aggressive options are necessary. Among these, plant species with allelopathic potential are notable, since they are rich in secondary metabolites with biological activity, can be manipulated for practical applications in agriculture and, thus, can be used to control weeds (JABRAN et al., 2015; FAROOQ et al., 2020).

The family Asteraceae comprises approximately 1,500 genera and 23,000 species (JUDD et al., 1999), including Mikania. This genus is mainly distributed in Neotropical regions and comprises about 430 species. Among them, there are some medicinal species, such as Mikania laevigata Sch. Beep. ex Baker. This plant is a wild shrub that grows in moist and well-drained places, mainly in the Atlantic Forest of Brazil from the state of São Paulo to the state of Rio Grande do Sul. Its leaves are petiolate, cordiform-deltoid, oval-lanceolate, tri- or penta-nerved and acute at the apex (CZELUSNIAK et al., 2012).
In this species, simple coumarin (1,2-benzopyrone) is considered the main chemical marker (ANVISA, 2011) and occurs in higher concentrations in the upper region of young leaves. Its presence in the plant results in a pleasant aroma reminiscent of vanilla (RAPOSO et al., 2017), and it is traditionally used to treat bronchitis, asthma and coughs (BIAVATTI et al., 2014). Regarding its allelopathic activity, 1,2-benzopyrone can promote or inhibit the growth of plants, since it interferes with cell division, elongation and differentiation, especially in roots. However, its effective responses are species specific and concentration dependent (ABENAVOLI et al., 2006; SALEH et al., 2015).

Despite the presence of coumarin in M. laevigata extracts and the proven allelopathic activity of ethanolic extract (BARATTO et al., 2008), the mechanism of action of these extracts on host plants is still unknown. In this context, based on using M. laevigata as a bioherbicide, the objective of the present study was to evaluate the in vitro phytotoxicity of aqueous and ethanolic extracts of $M$. laevigata leaves on the growth and oxidative stress of Lactuca sativa (lettuce) and Bidens pilosa (beggarticks). Lettuce seeds were used due to their rapid germination, linear growth and sensitivity to allelochemicals (FORMAGIO et al., 2014). The invasive species beggarticks was used because it is widely distributed and difficult to control in several agricultural crops (LACERDA et al., 2019). 


\section{Material and Methods}

\section{Collection of plant material}

Leaves of $M$. laevigata were collected from a mother plant grown in the Medicinal Plants Garden of the Department of Agriculture at the Federal University of Lavras, MG, Brazil. A collection was identified and incorporated into the herbarium of the Agricultural Research Company of Minas Gerais (EPAMIG), under registration number PAMG 57818.

\section{Obtaining extracts}

Leaves of M. laevigata were dehydrated at $40^{\circ} \mathrm{C}$ for $72 \mathrm{~h}$ and ground with a knife mill. To obtain the $10 \%$ $\left(\mathrm{w} / \mathrm{v}^{-1}\right)$ extracts, $30.0 \mathrm{~g}$ of ground leaves was weighed and subjected to extraction with water or ethanol to obtain the aqueous and ethanol extracts, separately. The extracts were obtained at room temperature using 3 cycles of $20 \mathrm{~min}$ of sonication, using $150 \mathrm{~mL}$ of the solvent in each cycle. The extracts were filtered through filter paper under vacuum, packed in a rotary evaporator flask, and concentrated to residue under reduced pressure at a maximum temperature of $40^{\circ} \mathrm{C}$ (BERTOLUCCI et al., 2008).

Aqueous and ethanolic extracts of the leaves of $M$. laevigata were subjected to thin layer chromatography (TLC) (Silica gel G, Merck, on 10 x $10 \mathrm{~cm}$ plates). The TLC analysis was performed using chloroform/MeOH P.A. (95:5) as the eluent and $5 \%\left(\mathrm{w} / \mathrm{v}^{-1}\right)$ methanolic $\mathrm{KOH}$ solution as the developer, and then viewed under UV light at $365 \mathrm{~nm}$. Coumarin (1,2-benzopyrone, SigmaAldrich) was used as the reference standard. Retention factors (Rf) were calculated for the fluorescent spots observed, according to the methodology in Wagner et al. (1984).

For the biological assays, crude extracts were resuspended in their respective extracting liquids at concentrations of $0.1,1.0,1.5,2.0$ and $3.0 \mathrm{mg} . \mathrm{mL}^{-1}$. The $\mathrm{pH}$ and osmotic potential of the working solutions were measured with a $\mathrm{pH}$ meter (PG1800, Gehaka) and by the Chardakov method (SALISBURY; ROSS, 1992), respectively, and the results are in Table 1.
Lactuca sativa L. and Bidens pilosa L. seed germination tests

Petri dishes $(9.0 \mathrm{~cm} \varnothing)$ autoclaved at $120^{\circ} \mathrm{C}$ for $30 \mathrm{~min}$ and containing a filter paper received $5.0 \mathrm{~mL}$ of each working solution (Table 1). The dishes with filter paper moistened with ethanolic solutions were dried in a laminar flow chamber for $12 \mathrm{~h}$. Then, $5 \mathrm{~mL}$ of distilled water was added and the dishes were capped, wrapped in plastic film, and kept in a BOD-type germination chamber with a photoperiod of $12 \mathrm{~h}$ and temperature of $24^{\circ} \mathrm{C}$ for L. sativa and $8 \mathrm{~h}$ and $25^{\circ} \mathrm{C}$ for B. pilosa. Distilled water was used as the control.

TABLE 1: $\mathrm{pH}$ and osmotic potential of the working solutions of Mikania laevigata.

\begin{tabular}{cccc}
\hline Extracts & $\begin{array}{c}\text { Concentrations } \\
\left(\mathbf{m g . m L} \mathbf{m}^{-1}\right)\end{array}$ & $\mathbf{p H}$ & $\mathbf{O P}(\mathbf{M P a})$ \\
\hline Control & Water & $\mathbf{6 . 8}$ & $\mathbf{0 . 0 0}$ \\
\hline \multirow{5}{*}{ Aqueous } & 0.1 & 6.46 & -0.022 \\
& 1.0 & 6.68 & -0.044 \\
& 1.5 & 6.51 & -0.067 \\
& 2.0 & 6.56 & -0.089 \\
Ethanolic & 3.0 & 5.72 & -0.100 \\
& 0.1 & 6.93 & -0.026 \\
& 1.0 & 6.75 & -0.030 \\
& 1.5 & 6.23 & -0.054 \\
& 2.0 & 6.72 & -0.080 \\
& 3.0 & 6.50 & -0.107 \\
\hline
\end{tabular}

$\mathrm{OP}=$ osmotic potential

The treatments were arranged in a completely randomized $2 \times 5$ factorial design and additional control, with four replicates of 50 seeds of $L$. sativa L. (cv. Grands rapids) and five replicates of 25 seeds of B. pilosa. Germination was evaluated daily for seven days to obtain the germination speed index (GSI) according to Franco et al. (2015) and percentage of germination according to Benincasa (1988). The seedlings were considered germinated when they had a radicle protrusion of $2 \mathrm{~mm}$ and were classified as normal or abnormal according to the Rules for Seed Analysis (BRASIL, 2009). The software GraphPad 7.3 was used to determine the extract concentrations capable of inhibiting seed germination by $50 \%\left(\mathrm{IC}_{50}\right)\left(\mathrm{mg} \cdot \mathrm{mL}^{-1}\right)$. 
Lactuca sativa L. and Bidens pilosa L. seedling growth bioassay

Seeds of L. sativa and B. pilosa were pregerminated in distilled water for $48 \mathrm{~h}$ and $72 \mathrm{~h}$, respectively. Soon after this, 40 seedlings (four replicates of 10) were transferred to gerbox boxes ( $11 \times 11 \times 3.5$ $\mathrm{cm}$ ) containing $6 \mathrm{~mL}$ of treatment solutions (Table 1). The boxes containing ethanolic solutions were exposed to a laminar flow for $12 \mathrm{~h}$ to evaporate the solvent and then $5 \mathrm{~mL}$ of distilled water was added. For the control, only $5 \mathrm{~mL}$ of distilled water was added. The boxes were then sealed and incubated in a BOD at $24^{\circ} \mathrm{C}$ for L. sativa and $25^{\circ} \mathrm{C}$ for B. pilosa with an 8-h photoperiod for 10 days (TIGRE et al., 2012). After this time interval, the hypocotyl-radicle axis $(\mathrm{mm})$, leaf area (length $\mathrm{x}$ width) $\left(\mathrm{mm}^{2}\right)$, and dry mass $(\mathrm{g})$ of the seedlings of each treatment were measured.

\section{Determination of hydrogen peroxide content and lipid peroxidation}

To evaluate the oxidative stress, $0.2 \mathrm{~g}$ of fresh mass of L. sativa and B. pilosa seedlings was macerated in liquid nitrogen. The resulting material was homogenized with aliquots of polyvinylpolypyrrolidone (PVPP) in $5 \mathrm{~mL}$ of trichloroacetic acid (TCA) $\left(0.1 \% \mathrm{w} / \mathrm{v}^{-1}\right)$ and centrifuged at 3,113 rotations per minute (RPM) for $15 \mathrm{~min}$ at $4^{\circ} \mathrm{C}$. The supernatant was used to determine the content of $\mathrm{H}_{2} \mathrm{O}_{2}$ and malondialdehyde (MDA). $\mathrm{H}_{2} \mathrm{O}_{2}$ content was measured according to Velikova et al. (2000). A total of $45 \mu \mathrm{L}$ of the extract was added to a reaction medium consisting of $45 \mu \mathrm{L}$ of $10 \mathrm{mmol}^{-\mathrm{L}^{-1}}$ potassium phosphate buffer ( $\mathrm{pH} 7$ ) and $90 \mu \mathrm{L}$ of 1.0 mol.L $\mathrm{L}^{-1}$ potassium iodide solution. The absorbance of the solutions was measured at $390 \mathrm{~nm}$. The calibration curve was constructed based on $0,5,15,25,35$, and $45 \mu \mathrm{M} \mathrm{H}_{2} \mathrm{O}_{2}$ solutions. A linear equation $(\mathrm{y}=0.014$ $\mathrm{x}+0.0069 \mathrm{R}^{2}=0.9831$ ) (VELIKOVA et al., 2000), where $\mathrm{y}$ is the absorbance and $\mathrm{x}$ is the concentration, was used to determine the $\mathrm{H}_{2} \mathrm{O}_{2}$ content. The results were expressed in $\mu \mathrm{mol}$ of $\mathrm{H}_{2} \mathrm{O}_{2} \cdot \mathrm{mg}^{-1}$ fresh mass of the seedlings.

Lipid peroxidation was indirectly assessed through the accumulation of malondialdehyde (MDA) and determined according to Cakmak and Horst (1991). The mixture was kept in a $95^{\circ} \mathrm{C}$ water bath for $30 \mathrm{~min}$ and cooled with an ice bath. The results were expressed in $\eta$ mol of MDA.mg ${ }^{-1}$ of fresh mass of seedlings. MDA content was estimated by the molar extinction coefficient of $\operatorname{MDA}\left(\varepsilon=155 \mathrm{mM}^{-1} \cdot \mathrm{cm}^{-1}\right)$ with the equation $\left(\mathrm{A}_{532}-\mathrm{A}_{660}\right) / \varepsilon$. Data represent the mean of three replicates of each extract at the concentrations dosed in duplicate.

\section{Statistical analysis}

The GSI and percentage of germination were transformed using the Box-Cox methodology (BOX; COX, 1964) to stabilize or reduce the existing variability and normalize the residues. A constant was added to the values because the Box-Cox transformation family is limited in the case of null values. The procedure proposed by Yamamura (1999) was adopted, with the parameter $\mathrm{c}=0.5$. The data were submitted to an analysis of variance and the means were compared with the Tukey test at 5\% probability, using the Assistat computational application (SILVA; AZEVEDO, 2009).

\section{Results}

The values of osmotic potential of the extracts varied between -0.022 to $-0.107 \mathrm{Mpa}$. The range of the pH was 6.46 to 6.5 and within the recommended limits for seed germination (Table 1).

The TLC study of the ethanolic and aqueous extracts resulted in a chromatogram with fluorescent spots, typical of coumarin, after development with methanolic $\mathrm{KOH}$ solution (Figure 1). The comparison of the chromatographic profile of the ethanolic (ET) and aqueous (AQ) extracts with the coumarin standard (C) showed that in both cases the substances of Rf 0.82 are coumarin 1,2-benzopyrone. 
FIGURE 1: Chromatographic profile of coumarin 1,2-benzopyrone (C) and ethanolic (ET) and aqueous (AQ) extracts.

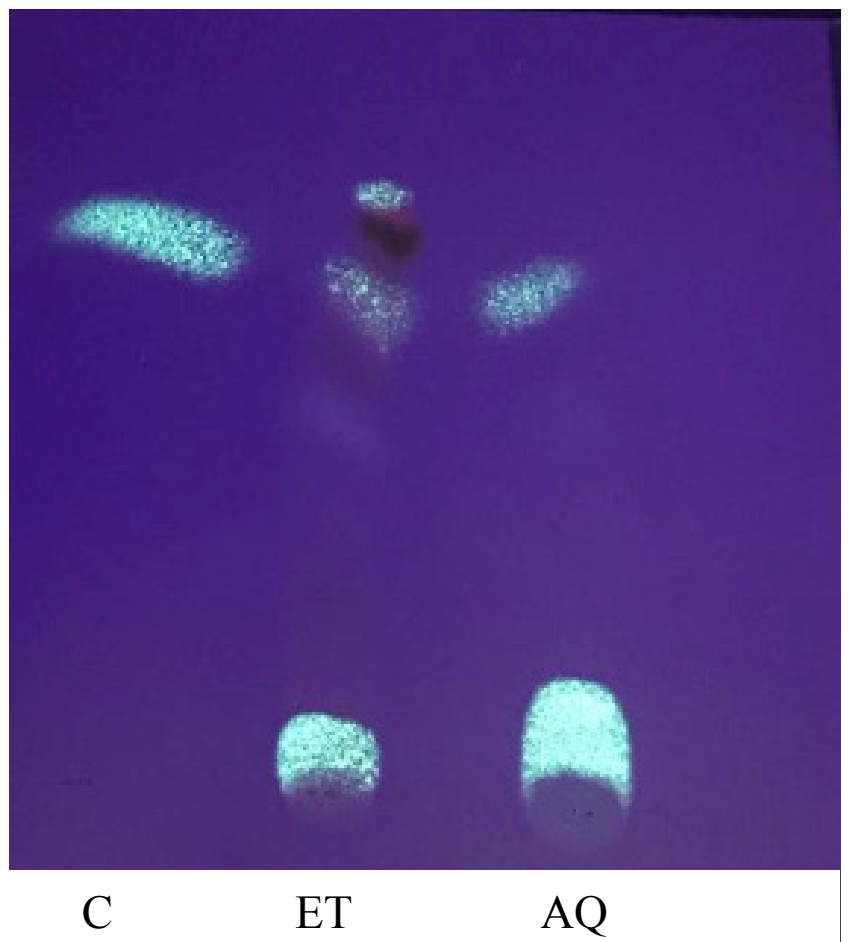

Germination of $L$. sativa seeds (Table 2) submitted to the ethanolic extract was significantly affected by the $1.5,2.0$ and $3.0 \mathrm{mg} \cdot \mathrm{mL}^{-1}$ concentrations, differing from the negative control. The values did not differ from the control at the lowest concentrations of the aqueous and ethanolic extracts. The germination speed index was negatively affected at the highest concentration of the ethanolic extract $\left(3.0 \mathrm{mg} \cdot \mathrm{mL}^{-1}\right)$, with a $94 \%$ reduction in relation to the control values. For the $B$. pilosa seeds, the extracts at their respective dilutions $(1.0,1.5,2.0$ mg. $\mathrm{mL}^{-1}$ ) stimulated germination and GSI. Reductions in relation to control values were observed only at the highest concentration (3.0 mg. $\mathrm{mL}^{-1}$ ) (Table 2). A 50\% reduction in germination of $B$. pilosa occurred at the concentration $1.17 \mathrm{mg} . \mathrm{mL}^{-1}$ of the aqueous extract, whereas a $50 \%$ reduction for $L$. sativa was observed for $3.84 \mathrm{mg} \cdot \mathrm{mL}^{-1}$. When the ethanol extract was used, the concentration for the species was similar. Three times less ethanolic extract was required to reduce $50 \%$ of the germination in L. sativa compared to the aqueous extract, demonstrating greater effectiveness at reducing germination (Table 2).

TABLE 2: Percentage of germination [G (\%)], $\mathrm{IC}_{50}$ values, and germination speed index (GSI) of Lactuca sativa and Bidens pilosa exposed to different concentrations $\left(0.1,1.0,1.5,2.0\right.$ and $\left.3.0 \mathrm{mg} . \mathrm{mL}^{-1}\right)$ of the aqueous and ethanolic extracts of Mikania laevigata.

\begin{tabular}{|c|c|c|c|c|c|c|c|}
\hline \multirow{2}{*}{$\begin{array}{l}\text { Working } \\
\text { solutions }\end{array}$} & \multicolumn{6}{|c|}{ Concentration $\left(\mathrm{mg} \cdot \mathrm{mL}^{-1}\right)$} & \multirow[b]{2}{*}{$\mathrm{IC}_{50}\left(\mathrm{mg} \cdot \mathrm{mL}^{-1}\right)$} \\
\hline & $\overline{0}$ & 0.1 & 1.0 & 1.5 & 2.0 & 3.0 & \\
\hline \multicolumn{8}{|c|}{$\begin{array}{c}\text { Lactuca sativa } \\
\text { G (\%) }\end{array}$} \\
\hline Ethanolic & $88 \mathrm{aA}$ & $97 \mathrm{aA}$ & $79 \mathrm{aB}$ & $17 \mathrm{bC}$ & $17 \mathrm{bC}$ & $2 \mathrm{aD}$ & 0.79 \\
\hline Aqueous & $88 \mathrm{aA}$ & $95 \mathrm{aA}$ & $88 \mathrm{aA}$ & $83 \mathrm{aA}$ & $83 \mathrm{aA}$ & $7 \mathrm{aB}$ & 3.84 \\
\hline \multicolumn{8}{|c|}{ GSI } \\
\hline Ethanolic & $4.94 \mathrm{aA}$ & $4.23 \mathrm{aA}$ & $1.35 \mathrm{bB}$ & $0.75 \mathrm{bC}$ & $0.9 \mathrm{bBC}$ & $0.30 \mathrm{aD}$ & \\
\hline Aqueous & $4.94 \mathrm{aA}$ & $5.12 \mathrm{aA}$ & $2.25 \mathrm{aB}$ & $1.98 \mathrm{aB}$ & $1.61 \mathrm{aB}$ & $0.33 \mathrm{aC}$ & \\
\hline \multicolumn{8}{|c|}{$\begin{array}{c}\text { Bidens pilosa } \\
\text { G }(\%)\end{array}$} \\
\hline Ethanolic & $30 \mathrm{bA}$ & $65 \mathrm{aA}$ & $48 \mathrm{aA}$ & $70 \mathrm{aA}$ & $65 \mathrm{aA}$ & $3 \mathrm{bD}$ & 1.17 \\
\hline Aqueous & $30 \mathrm{bA}$ & $50 \mathrm{aA}$ & $53 \mathrm{aA}$ & $40 \mathrm{bA}$ & $33 \mathrm{bA}$ & $54 \mathrm{aA}$ & 1.14 \\
\hline \multicolumn{8}{|c|}{ GSI } \\
\hline Ethanolic & $0.69 \mathrm{bB}$ & $0.89 \mathrm{aA}$ & $0.89 \mathrm{aA}$ & $1.23 \mathrm{aA}$ & $1.01 \mathrm{aA}$ & $0.12 \mathrm{bB}$ & \\
\hline Aqueous & $0.69 \mathrm{bB}$ & $0.75 \mathrm{aA}$ & $1.0 \mathrm{aAB}$ & $0.70 \mathrm{bB}$ & $0.54 \mathrm{bA}$ & $1.9 \mathrm{aA}$ & \\
\hline
\end{tabular}

Averages followed by the same capital letter in the column and lower case in the row for each species do not differ by the Tukey test ( $5 \%$ probability). 


\section{Initial growth}

Initial growth responses varied according to the nature and concentration of the solution used, as well as according to the target species (Figure 2). In general, the ethanolic solutions of $M$. laevigata demonstrated a phytotoxic effect on $L$. sativa and B. pilosa. In $L$. sativa, these solutions caused greater reductions in radicular length than the aqueous solutions (Figure $2 \mathrm{~A}, 2 \mathrm{~B}$ and $2 \mathrm{C}$ ). At all concentrations of the aqueous

FIGURE 2: Mean hypocotyl length ( $\mathrm{mm})$, radicle length $(\mathrm{mm})$, leaf area $\left(\mathrm{mm}^{2}\right)$ and dry mass (g) values of seedlings of Lactuca sativa (A, C, E and G) and Bidens pilosa $(\mathrm{B}, \mathrm{D}, \mathrm{F}$ and $\mathrm{H})$, respectively, grown in the presence of aqueous and ethanolic solutions of Mikania laevigata and a control of distilled water.

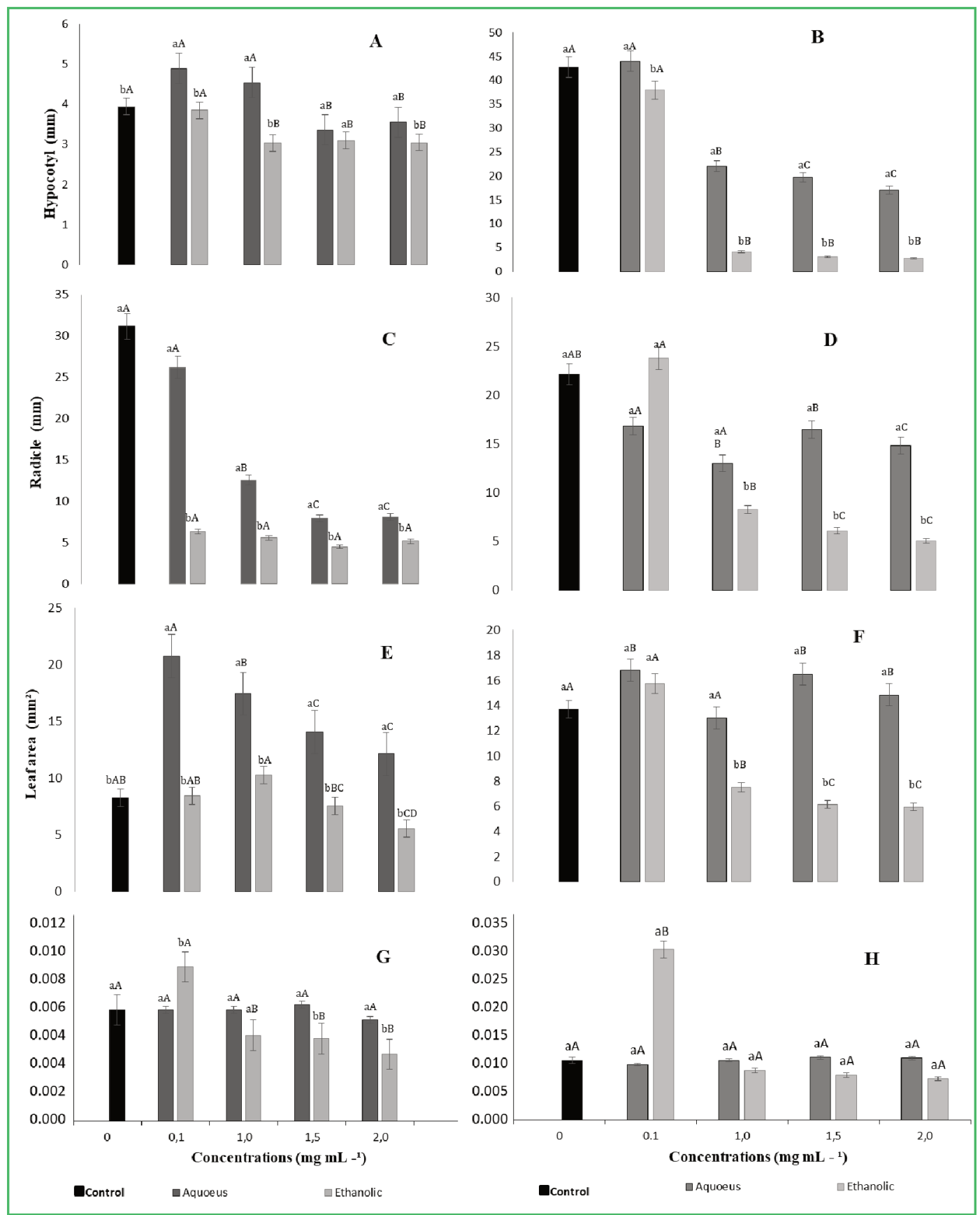

Means followed by the same letters do not differ statistically from each other. Lowercase letters for the extract in each concentration and uppercase letters for the concentration within each extract. The bars indicate standard error $( \pm \mathrm{SE})$. $\mathrm{N}=50$. 
extract, the seedlings increased leaf area in relation to the control. Dry mass of seedlings grown in the lowest concentrations of the extracts remained statistically the same as the control values. The greatest stimulus was caused by the ethanolic and aqueous solutions $(0.1$ mg. $\mathrm{mL}^{-1}$ ) (Figure $2 \mathrm{G}$ and $2 \mathrm{H}$ ).

The 2.0 and $3.0 \mathrm{mg} \cdot \mathrm{mL}^{-1}$ ethanolic extracts strongly diminished the development of B. pilosa compared to the control. Particularly for the growth of shoots and radicles, the greatest reductions occurred at the 2.0 $\mathrm{mg} \cdot \mathrm{mL}^{-1}$ concentration, fitting the dose-reduction (Figure $2 \mathrm{C}$ to $2 \mathrm{D}$ ). All the seedlings cultivated in $3 \mathrm{mg} \cdot \mathrm{mL}^{-1}$ of the ethanol extract necrosed, making subsequent analyses impossible.
Radicle size was approximately $77 \%$ smaller compared to the control when the $2.0 \mathrm{mg} \cdot \mathrm{mL}^{-1}$ ethanolic solution was used. As for morphology, there was thickening of the median region of the radicle in the two studied species (L. sativa and B. pilosa).

It is noteworthy that the aqueous solutions of $M$. laevigata up to the concentration $1.0 \mathrm{mg} \cdot \mathrm{mL}^{-1}$ stimulated hypocotyl growth of $L$. sativa (Figure 2A), indicating a dose stimulus. Similarly, leaf area of $L$. sativa (Figure 2E) and B. pilosa (Figure 2F) increased in the presence of the aqueous extract, with values higher than those observed for the control.

TABLE 3: Hydrogen peroxide $\left(\mathrm{H}_{2} \mathrm{O}_{2}\right)$ content in seedlings of Lactuca sativa and Bidens pilosa submitted to five concentrations $\left(0,0.1,1.0,1.5,2\right.$ and 3 ๆmol.g- $\left.{ }^{1}\right)$ of aqueous and ethanolic extracts of Mikania laevigata.

\begin{tabular}{ccccc}
\hline \multicolumn{5}{c}{$\mathbf{H}_{\mathbf{2}} \mathbf{O}_{\mathbf{2}} \mathbf{( 0 )}$} \\
\hline $\begin{array}{c}\text { Concentrations } \\
\left(\mathbf{m g . m L} \mathbf{H}^{-1}\right)\end{array}$ & $\begin{array}{c}\text { Aqueous } \\
\text { extract }\end{array}$ & $\begin{array}{c}\text { Ethanolic } \\
\text { extract }\end{array}$ & $\begin{array}{c}\text { Aqueous } \\
\text { extract }\end{array}$ & $\begin{array}{c}\text { Ethanolic } \\
\text { extract }\end{array}$ \\
\hline 0 & $0.40 \mathrm{f}$ & $0.40 \mathrm{f}$ & $0.60 \mathrm{e}$ & $0.60 \mathrm{e}$ \\
0.1 & $1.10 \mathrm{ab}$ & $0.53 \mathrm{~cd}$ & $1.10 \mathrm{~d}$ & $1.20 \mathrm{~d}$ \\
1.0 & $0.85 \mathrm{bc}$ & $0.13 \mathrm{e}$ & $2.10 \mathrm{c}$ & $3.20 \mathrm{~d}$ \\
1.5 & $0.58 \mathrm{~cd}$ & $1.35 \mathrm{a}$ & $3.40 \mathrm{c}$ & $6.40 \mathrm{~d}$ \\
2.0 & $1.31 \mathrm{a}$ & $1.27 \mathrm{a}$ & $4.40 \mathrm{abc}$ & $7.20 \mathrm{~d}$ \\
3.0 & $1.21 \mathrm{ab}$ & - & $7.30 \mathrm{a}$ & - \\
\hline C.V. $(\%)$ & & & & 16 \\
\hline
\end{tabular}

C.V. - Coefficient of variation in percentage; FM - Fresh mass; - Not evaluated due to necrosis of plant tissues.

TABLE 4: Lipid peroxidation measured by malonaldehyde (MDA) content in seedlings of Lactuca sativa and Bidens pilosa submitted to five concentrations $\left(0,0.1,1.0,1.5,2\right.$ and $\left.3 \mathrm{mg} \cdot \mathrm{mL}^{-1}\right)$ of aqueous and ethanolic extracts of Mikania laevigata.

\begin{tabular}{|c|c|c|c|c|}
\hline \multicolumn{5}{|c|}{ MDA ( } \\
\hline & \multicolumn{2}{|c|}{ Lactuca sativa } & \multicolumn{2}{|c|}{ Bidens pilosa } \\
\hline $\begin{array}{l}\text { Concentrations } \\
\left(\mathrm{mg}^{-m^{-1}}\right)\end{array}$ & $\begin{array}{c}\text { Aqueous } \\
\text { extract }\end{array}$ & $\begin{array}{c}\text { Ethanolic } \\
\text { extract }\end{array}$ & $\begin{array}{c}\text { Aqueous } \\
\text { extract }\end{array}$ & $\begin{array}{c}\text { Ethanolic } \\
\text { extract }\end{array}$ \\
\hline 0 & $4.0 \mathrm{~g}$ & $4.0 \mathrm{~g}$ & $21.0 \mathrm{f}$ & $21.0 \mathrm{f}$ \\
\hline 0.1 & $13.0 \mathrm{f}$ & $33.0 \mathrm{e}$ & $48.0 \mathrm{c}$ & $113.0 \mathrm{c}$ \\
\hline 1.0 & $38.0 \mathrm{de}$ & 43.0 cde & $113.0 \mathrm{~d}$ & $172.0 \mathrm{~b}$ \\
\hline 1.5 & 44.0 cde & $55.0 \mathrm{c}$ & $139.0 \mathrm{c}$ & $203.0 \mathrm{a}$ \\
\hline 2.0 & $50.0 \mathrm{~cd}$ & $143.0 \mathrm{a}$ & $206.0 \mathrm{a}$ & $215.0 \mathrm{a}$ \\
\hline 3.0 & $74.0 \mathrm{~b}$ & - & $230.0 \mathrm{e}$ & - \\
\hline
\end{tabular}

C.V. - Coefficient of variation in percentage; FM - Fresh mass; - Not evaluated due to necrosis of plant tissues. 


\section{Hydrogen peroxide content and lipid peroxidation (MDA)}

In L. sativa, the aqueous (Tables 3 and 4 ) (2.0 and $3.0 \mathrm{mg} \cdot \mathrm{mL}^{-1}$ ) and ethanolic (1.5 and 2.0 $\mathrm{mg} \cdot \mathrm{mL}^{-1}$ ) extracts stimulated the increase of $\mathrm{H}_{2} \mathrm{O}_{2}$ by approximately $1,250 \%$ and lipid peroxidation (MDA) by approximately $1,800 \%$ in relation to the control (Tables 3 and 4). Seedlings of B. pilosa grown in the 2.0 and $3.0 \mathrm{mg} \cdot \mathrm{mL}^{-1}$ aqueous extracts increased production of $\mathrm{H}_{2} \mathrm{O}_{2}$ by approximately 700 and $1,200 \%$, respectively, compared to the control. The increase in the levels of this reactive oxygen species (ROS) (i.e., $\mathrm{H}_{2} \mathrm{O}_{2}$ ) were followed by an increase in lipid peroxidation (MDA) (Tables 3 and 4), which had values approximately $1,000 \%$ greater than the control values. The seedlings of both species tested exhibited necrosis for the $3.0 \mathrm{mg} \cdot \mathrm{mL}^{-1}$ ethanolic extract, hindering subsequent evaluations.

\section{Discussion}

When the highest concentrations of the solutions were used, germination and vigor of the seedlings were reduced, while these aspects were stimulated at the lower concentrations. According to Uddin et al. (2014), allelopathic activity in different physiological processes is concentration dependent, or at least it is expected that stimuli occur at low concentrations and inhibitions at high concentrations.

In general, allelochemicals act by modifying the germination curve, by shortening (kurtosis), broadening, or producing a complex pattern in the curve along the time axis. These changes indicate changes in metabolic reactions of the seeds that result in lower germinability (SILVEIRA et al., 2014).

It is likely that the coumarin detected by TLC is responsible for the allelopathic effects observed, or that it, depending on its concentration, is acting in synergy with other substances. Coumarin [1,2-benzopyrone] was identified in the extracts of $M$. laevigata, mainly in ethanolic extracts, as observed by Gasparetto et al. (2010) and Czelusniak et al. (2012).
In the initial growth of the seedlings, radicles of L. sativa were more sensitive to the presence of allelochemicals, mainly to ethanol extracts of $M$. laevigata that are rich in coumarin. Pure coumarin is widely known for its ability to inhibit root development, as described by Takemura et al. (2013) where root development of lettuce (L. sativa) was compromised.

At the highest concentrations of the extracts, the production of ROS exceeded the capacity of cells to control $\mathrm{H}_{2} \mathrm{O}_{2}$, leading to damage by lipid peroxidation (XIE et al., 2019). Plants respond to biotic or abiotic stress through a complex network of molecular and biochemical processes, allowing them to overcome adverse situations and adapt. Calcium phosphates, inositol and ROS are common elements of signaling pathways during both biotic and abiotic stress (HE et al., 2018).

ROS act as local and systemic secondary messengers to trigger plant responses, such as the expression of stress-sensitive genes, as in the case of those linked to stomatal opening and closing, and cell wall reinforcement (SINGH et al., 2017). As signaling and protective factors, excessive generation of ROS signals toxicity during many processes of biotic and abiotic stress (BORGES et al., 2014; COELHO et al., 2017).

The excessive production of ROS in L. sativa and $B$. pilosa culminated in the rupturing of biological membranes, signaled by the MDA content. This result was described by Pergo et al. (2008) for B. pilosa treated with coumarin. The substance increased the content of conjugated dienes, indicating oxidative damage. The correlation between the antioxidant defense system and coumarin-induced stress resistance was also observed in two rice cultivars by Mahmood et al. (2013).

The aqueous and mainly the ethanolic solutions of M. laevigata were effective at controlling the germination and initial growth of the two species studied, as well as at inducing the production of hydrogen peroxide and increasing malonaldehyde content, demonstrating their potential as bioherbicides. 
The ethanolic extract of $M$. laevigata at the 3 $\mathrm{mg} \cdot \mathrm{mL}^{-1}$ concentration is a promising source of a natural herbicide, since it induces oxidative stress and necrosis of plant tissues.

\section{References}

ABENAVOLI, M. R.; CACCO, G.; SORGONA, A.; MARABOTTINI, R.; PAOLACCI, A. R.; CIAFFI, M.; BADIANI, $M$. The inhibitory effects of coumarin on the germination of durum wheat (Triticum turgidum ssp. durum, CV. Simeto) seeds. Journal of Chemical Ecology, Tampa, v. 32, p. 489-506, 2006.

ANVISA - AGÊNCIA NACIONAL DE VIGILÂNCIA SANITÁRIA. Instrução Normativa 7, de 20 de setembro de 2011. Formulário de Fitoterápicos da Farmacopeia Brasileira. Determina a publicação da lista de medicamentos fitoterápicos de registro simplificado. Disponível em: http://portal.anvisa.gov. br/documents/33832/259456/Formulario_de_Fitoterapicos_da_ Farmacopeia_Brasileira.pdf.

BARATTO, L.; LANG, K. L.; VANZ, D. C.; REGINATTO, F. H.; OLIVEIRA, J. B.; FALKENBERG, M. Investigação das atividades alelopática e antimicrobiana de Mikania laevigata (Asteraceae) obtida de cultivos hidropônico e tradicional. Revista Brasileira de Farmacognosia, Curitiba, v. 18 n. 4, p. 577-582, 2008.

BENINCASA, M. M. P. Análise de crescimento das plantas. Jaboticabal: FUNEP, 1988. 41 p.

BERTOLUCCI, S. K.; PEREIRA, A. B.; PINTO, J. E.; AQUINO, R. J. A.; OLIVEIRA, A. B.; BRAGA, F. C. Development and validation of an RP-HPLC method for quantification of Cinnamic Acid derivatives and kaurane-type diterpenes in Mikania laevigata and Mikania glomerata. Planta Medica, Stuttgart, v. 75, n. 3, p. 280-285, 2008.

BIAVATTI, M. W.; KOERICH, C. A.; HENCK, C. H.; SUCATELLI, E.; MARTINELI, F. H.; BRESOLIN, T. B.; LEITE, S. N. Coumarin content and physicochemical profile of Mikania laevigata extracts. Zeitschrift für Naturforschung, Tübingen, v. 59, n. 3, p. 197-200, 2014.

BORGES, A. A.; JIMÉNEZ-ARIAS, D.; EXPÓSITORODRÍGUEZ, M.; SANDALIO, L. M.; PÉREZ, J. A. Priming crops against biotic and abiotic stresses: $\mathrm{MSB}$ as a tool for studying mechanisms. Frontiers in Plant Science, Melbourne, v. 5, n. 2, p. 642-645, 2014.

BOX, G. E. P.; COX, D. R. An analysis of transformations. Journal of the Royal Statistical Society. Series B (Methodological), London, v. 26, p. 211-252, 1964.

BRASIL - MINISTÉRIO DA AGRICULTURA. Regras para análises de sementes. Brasília: SNAD/DNDV/CLAV, 2009. 398 p. CAKMAK, E.; HORST, J. H. Effects of aluminum on lipidperoxidation, superoxide dismutase, catalase, and peroxidase activities in root tips of soya bean (Glycine max). Physiologia Plantarum, Lund, v. 83, n. 3, p. 463-468, 1991.

COElHO, E. M. P.; BARBOSA, M. C.; MITO, M. S.; MANTOVANELLI, G. C.; OLIVEIRA, R. S. JR; ISHII-
IWAMOTO, E. L. The activity of the antioxidant defense system of the weed species Senna obtusifolia L. and its resistance to allelochemical stress. Journal of Chemical Ecology, Tampa, v. 43, n. 7, p. 725-738, 2017.

CZELUSNIAK, K. E.; BROCCO, A.; PEREIRA, D. F.; FREITAS, G. B. L. Farmacobotânica, fitoquímica e farmacologia do guaco: revisão considerando Mikania glomerata Sprengel e Mikania laevigata Schulyz Bip. ex Baker. Revista Brasileira de Plantas Medicinais, Botucatu, v. 14, n. 2, p. 400-409, 2012.

FORMAGIO, A. S. N.; MASETTO, T. E.; VIEIRA, M. do C.; ZÁRATE, N. A. H.; MATOS, A. I. N. de; VOLOBUFF, C. R. F. Potencial alelopático e antioxidante de extratos vegetais. Bioscience Journal, Uberlândia, v. 30, n. 2, p. 629-638, 2014.

FAROOQ, N.; ABBAS, T.; TANVEER, A.; JABRAN, K. Allelopathy for weed management. In: MÉRILLON, J. M.; RAMAWAT, K. (Ed.). Co-evolution of secondary metabolites. Reference Series in Phytochemistry. Cham: Springer, 2020. p. 505-519.

FRANCO, D. M.; SILVA, E. M.; SALDANHA, L. L.; ADACHI, S. A.; SCHLEYA, T. R.; RODRIGUES, T. M.; DOKKEDAL, A. L.; NOGUEIRA, F. T. S.; ROLIM DE ALMEIDA, L. F. Flavonoids modify root growth and modulate expression of Short-Root and HD-ZIP III. Journal of Plant Physiology, Tübingen, v. 188, n. 2. p. 89-95, 2015.

GASPARETTO, J. C.; CAMPOS, F. R.; BUDEL, J. M.; PONTAROLO, R. Mikania glomerata Spreng. e M. laevigata Sch. Bip. ex Baker, Asteraceae: estudos agronômicos, genéticos, morfoanatômicos, químicos, farmacológicos, toxicológicos e uso nos programas de fitoterapia do Brasil. Revista Brasileira de Farmacognosia, Curitiba, v. 20, n. 4, p. 627-640, 2010.

HE, M.; HE, C. Q.; DING, N. Z. Abiotic stresses: general defenses of land plants and chances for engineering multistress tolerance. Frontiers in Plant Science, Melbourne, v. 9, p.17711789, 2018.

ISMAIL, B. S.; HALIMSHAH, S.; WAN, J. W. A.; YUSOFF, N. Allelopathic potential of the leaf and seed of Pueraria javanica Benth. on the germination and growth of three selected weed species. Sains Malaysiana, Bangi, v. 4, n. 45, p. 517-521, 2016.

JABRAN, K.; MAHAJAN, G.; SARDANA, V.; CHAUHAN, B. S. Allelopathy for weed controlin agricultural systems. Crop Protection, Guildford, v. 72, p. 57-65, 2015.

JUDD, W. S.; STEVENS, P. F.; CAMPBELL, C. S.; KELLOGG, E. A. Plant systematics: a phylogenetic approach. Sunderland: Sinauer, 1999. $350 \mathrm{p}$.

LACERDA, A. L. S.; FILHO, R. V.; SOUZA, Z. M.; TORRES, J. L. R. Use of different doses of glyphosate to control invasive plants: 'Bidens pilosa', 'Commelina benghalensis', 'Digitaria insularis', 'Ipomoea grandiofolia' and 'Tridax procumbens', Australian Journal of Crop Science, Lismore, v. 13, n. 4, p. 529-535, 2019.

MAHMOOD, K.; KHAN, M. B.; SONG, Y. Y.; YE, M.; BAERSON, S. R.; ZENG, R. S. Differential morphological, cytological and biochemical responses of two rice cultivars to coumarin. Allelopathy Journal, New York, v. 31, p. 281-296, 2013.

MUSHTAQ, W.; SIDDIQUI, M. B.; HAKEEM, K. R. Allelopathic control of native weeds. In: MUSHTAQ, W.; SIDDIQUI, M. 
B.; HAKEEM, K. R. (Ed.). Allelopathy. Springer Briefs in Agriculture. Cham: Springer, 2020. p. 53-59.

PERGO, E. M.; ABRAHIM, D.; SILVA, P. C. S.; KERN, K. A.; SILVA, L. J.; VOLL, E.; IWAMOTO, L. I. Bidens pilosa L. exhibits high sensitivity to coumarin in comparison with three other weed species. Journal of Chemical Ecology, Tampa, v. 34, n. 4, p. 499507, 2008.

RAPOSO, J. D.A.; NEVES, F. G.; AGUIAR, W.A.; MAGALHÃES, P. M.; SILVA, R.; MAIA, J. G. S.; MOURÃO, R. H. V. Cultivation of guaco (Mikania laevigata Sch. Bip. ex Baker) in the lower amazon river and monitoring of coumarin, its principal active constituent. Revista Fitos, Rio de Janeiro, v. 10, n. 3, p. 227-237, 2017.

SALISBURY, F. B.; ROSS, C. Plant physiology. Belmont: Wadsworth, 1992. $682 \mathrm{p}$.

SALEH, A. M.; MADANY, M. M. Y.; GONZÁLEZ, L. The effect of coumarin application on early growth and some physiological parameters in faba bean (Vicia faba L.). Journal of Plant Growth Regulation, Berlin, v. 34, n. 2, p. 233-241, 2015.

SILVA, F. A. S.; AZEVEDO, C. A. V. Principal components analysis in the software Assistat-Statistical Attendance. In: WORLD CONGRESSO N COMPUTERS IN AGRICULTURE, 7, 2009, Orlando. Proceedings... Reno: American Society of Agricultural and Biological Engineers, 2009. CD-ROM-1.

SILVEIRA, B. D.; HOSOKAWA, R. T.; NOGUEIRA, A. C.; WEBER, V. P. Atividade alelopática de Araucaria angustifolia (Bertol.) Kuntze na germinação e crescimento inicial de Lactuca sativa L. Ciência Florestal, Santa Maria, v. 24, n. 1, p. 79-85, 2014.

SINGH, R.; PARIHAR, P.; SINGH, S.; MISHRA, R. K.; SINGH, V. P.; PRASAD, S. M. Reactive oxygen species signaling and stomatal movement: Current updates and future perspectives.

Redox Biology, Indianapolis, v. 11, n. 2, p. 213-218, 2017.
TAKEMURA, T.; KAMO, T.; SAKUNO, E.; HIRADATE, S.; FUJII, Y. Discovery of coumarin as the predominant allelochemical in Gliricidia sepium. Journal of Tropical Forest Science, Kuala Lumpur, v. 25, n. 2, p. 268-272, 2013.

TIGRE, R. C.; SILVA, N. H.; SANTOS, M. G.; HONDA, N. K.; FALCÃO, E. P.; PEREIRA, E. C. Allelopathic and bioherbicidal potential of Cladonia verticillaris on the germination and growth of Lactuca sativa. Ecotoxicology and Environmental Safety, Amsterdam, v. 84, p. 125-32, 2012.

UDDIN, MD. N.; ROBINSON, R. W.; CARIDI, D. Phytotoxicity induced by Phragmites australis: an assessment of phenotypic and physiological parameters involved in germination process and growth of receptor plant, Journal of Plant Interactions, London, v. 9, n. 1, p. 338-353, 2014.

VELIKOVA, V.; YORDANOV, I.; EDREVA, A. Oxidative stress and some antioxidant systems in acid rain treated bean plants: protective role of exogenous polyamines. Plant Science, Davies, v. 151, p. 59-66, 2000.

WAGNER, H.; BLADT, S.; ZGAINSKY E. M. Plant drug analysis a thin layer chromatography Atlas. Berlin: Springer Verlag, 1984. $320 \mathrm{p}$.

XIE, X.; HE, Z.; CHEN, N.; TANG, Z.; WANG, Q.; CAI, Y. The roles of environmental factors in regulation of oxidative stress in plant. BioMed Research International, Cairo, v. 2019. n. 2, p. 1-11, 2019.

YAMAMURA, K. Transformation using $(x+0.5)$ to stabilize the variance of populations. Researches on Population Ecology, Sapporo, v. 42, p. 229-234, 1999. 